\title{
Implementation of the Futsal Field Ordering Platform using the UCD Method
}

\author{
Agustia Hananto ${ }^{1}$ \\ Technology Information \\ Master of Computer Science \\ University of Budi Luhur \\ agustia.hananto@gmail.com
}

\author{
Muhamad Mammun ${ }^{2}$ \\ Information Systems Study Program \\ School of Engineering and Computer Science \\ Universitas Buana Perjuangan Karawang \\ mamun20@gmail.com
}

\author{
Nurhayati $^{3}$ \\ Technology Information \\ Master of Computer Science \\ University of Budi Luhur \\ hayatinur10@gmail.ac.id
}

\begin{abstract}
- the development of information technology is exploding. We cannot separate the need for information from the use and use of computers. With a computerized information system, the work done will be more effective and accurate. Karawang Futsal is a sports venue in the Karawang Regency. Using the futsal ordering system is still manual, the data input system which is still recording in the ledger, making reports is not accurate because of frequent miscalculations that result in making reports not on time because all processes are done. Therefore, with the existence of a computer system, all the needs for everything in the Karawang Regency Futsal will run.
\end{abstract}

Keywords-Information systems, computerized, futsal.

\section{INTRODUCTION}

Information Technology is a technology that is developing. The information available can take place, and. Information that is accurate and can be accessed by anyone, anywhere and anytime, with information systems using computers as a medium that makes it easier for someone to manage data. Good data and information management are very important for the needs of an organization, those related to business. One example is the futsal field ordering system.

Futsal court booking is a booming business that provides futsal field booking services. Business processes in place for futsal field bookings still require customers to come in making an order and arrange the desired booking schedule. So customers do not know the empty schedule. Every day the clerk records the orders from the customers in the order book. On the day of the order, the customer makes an order for payment. This can cause errors in recording.

This manual field booking system is inconvenient for the field user and becomes less efficient in terms of time, energy, and cost because the user must go to any existing futsal venue to check the schedule and field booking. Based on these constraints, it is very much needed a system with webbased futsal field booking design, in terms of accurate validation for scheduling and field booking problems. Web applications are easier to access. A website can be accessed from anywhere as long as there is an internet network. This application helps consumers to see the field schedule and can order according to the desired time.

This application is also designed so that owners of futsal venues can manage and manage their field schedules. Using this system is able to manage futsal field bookings, , and. This web-based futsal field booking application is expected to help users to provide information about the field and make reservations and.

\section{THEORETICAL BASIS}

\section{A. System}

A system is a unit comprising components or elements that are linked and arranged in such a way as to facilitate the flow of information that serves to achieve a goal [5], the system is a collection of sub-systems, elements, procedures that are integrated to achieve certain goals, such as target information or goals. Meanwhile, the system is a collection of components that work together to achieve a goal [6].

\section{B. Information}

Information is very important for the company in making every decision, information comes from the ancient French language, information in 1387 which was taken from the Latin information which means "outline, concept, idea" [3].

Information is data processed into a form that is more useful and more meaningful for those who receive it, while the data is a source of information that describes a real event Information is data that has been organized and has had uses and benefits [4].

\section{Black-Box Testing}

The Tester uses behavioral tests (also called Black-Box Tests), often used to find bugs in high-level operations, at feature levels, operational profiles, and customer scenarios. The tester can make functional black box testing based on what the system has to do. Behavioral testing involves a detailed understanding of the application domain, the business problems that are solved by the system and the system's mission. Behavioral tests are best by testers who understand system design, at least at a high level so they can find common bugs for this design [2].

\section{UCD (User Centered Design)}

UCD is the user's relation to the whole process. Users/users not only provide input on the design concept but also must be involved in all aspects, including the stages of implementation in the system that will affect their activities. the user is also involved in the initial testing and evaluation and design. But depending on the complexity of the system to be built, there is [1].

\section{RESEARCH METHODS}

Before The research method used is the waterfall model. The waterfall comprises several stages of activity flow that goes one direction from the beginning to the end of the 
system development project. The waterfall SDLC model provides a sequential or sequential software life-flow approach starting from the analysis, design, coding, testing, and support stages. Here is a picture of the waterfall model:

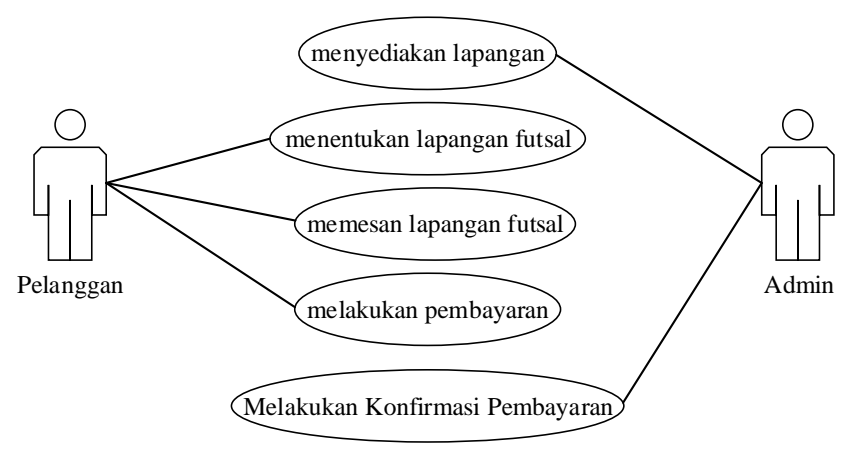

Fig. 1. Use Case Diagram

\section{A. Analysis}

The author analyzes the needs of the application to be built. The analysis is done by direct observation of research objects. It made observations to retrieve data approved by the object of research for study by researchers.

\section{B. The design}

The design is used to make an initial description of the application to be made, in system modeling, the application interface for photocell field ordering in Karawang.

\section{Making Program Code}

At this stage, the authors do the application coding by the design that has been made.

D. Testing

They carry the test out to test both the logic and functionality of the application that has been made, to ensure the application runs as desired and according to its function. In this study, the study conducted testing with the black box method.

\section{E. Maintenance}

I do maintenance after the application is running by checking the running of the application and backing up the data in a scaled way.

\section{RESULT AND DISCUSSION}

\section{A. Analysis of Current System Procedures}

Explain the flow of new systems running in the form of information flow patterns that occur through documents, reports, processes or procedures that occur in the new system that is running.

\section{B. System Architecture}

I built This system to provide information about futsal field reservations in the city of Karawang through a media website. This futsal field data object is managed by an admin:

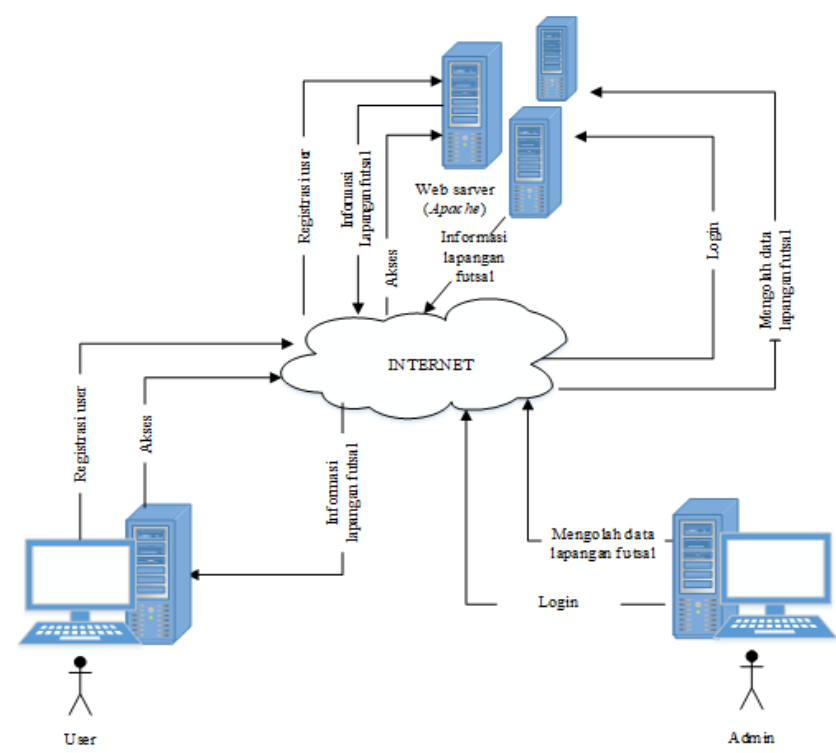

Fig. 2. System Architecture

C. Database

1. Class Diagram

Class Diagram is the most important element in objectoriented systems, the class describes a building block system. Class Diagram has other features and characteristics, while those listed in this system are those that are related to the design of a futsal field reservation system, the following class diagram on the Futsal Field Order Information System:

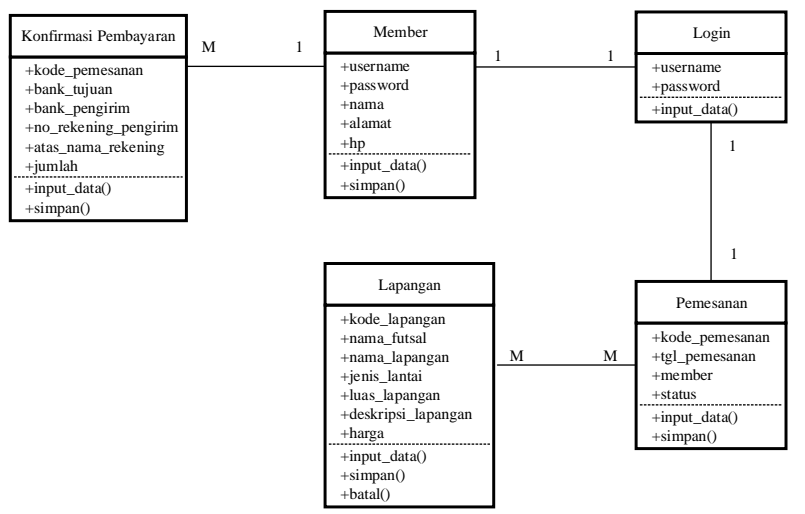

Fig. 3. Class Diagram

D. User Interface

1. Website Mann Page

This main output page is the first page that will appear when the user enters the website address of the Karawang Regency Futsal Field Booking Platform website. This main page comprises several main menus, the Home menu, Today's Booking menu, the Schedule menu, the Booking menu and the Login menu, which are enabled to make it easier for users to find out futsal field booking information. Next Website Home Page Display: 


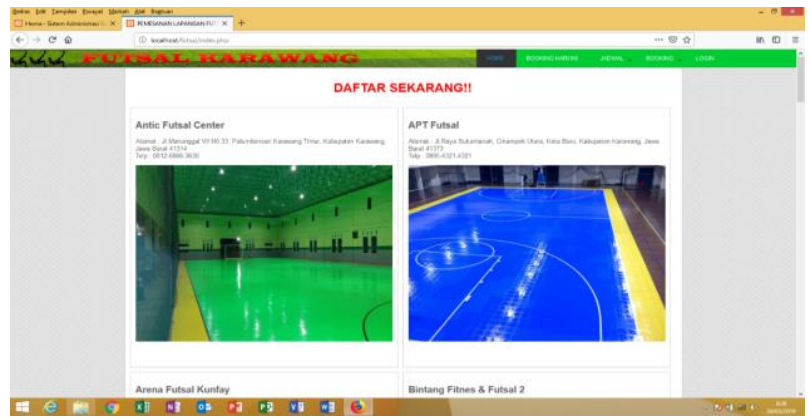

Fig. 4. Admin Page

2. Admin Login page

Admin login input page to use all the admin features must first log in, Next is the Admin Login Page Display:

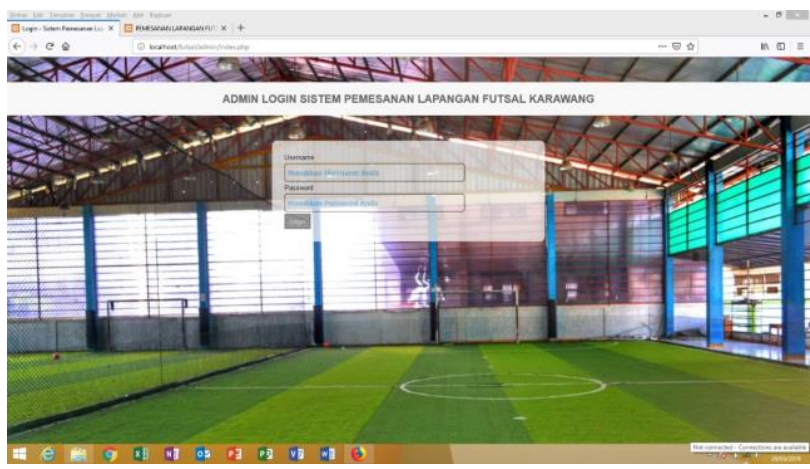

Fig. 5. Login Page

3. Member Registration page

On the input page of this member registration, a data form will appear that the user must fill in if he wants to register as a member. The appearance of member registration pages is:

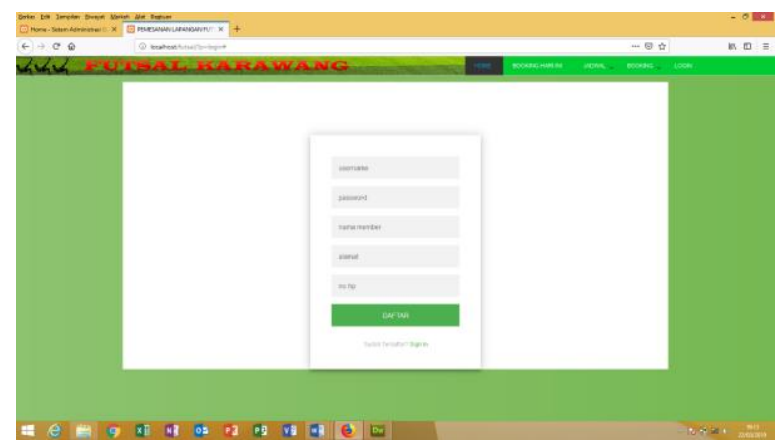

Fig. 6. Registration Page

4. Add Booking page

On the addition data booking input page, a data form will appear that the user must fill in if he wants to book a futsal field. The appearance of the additional data booking page is:

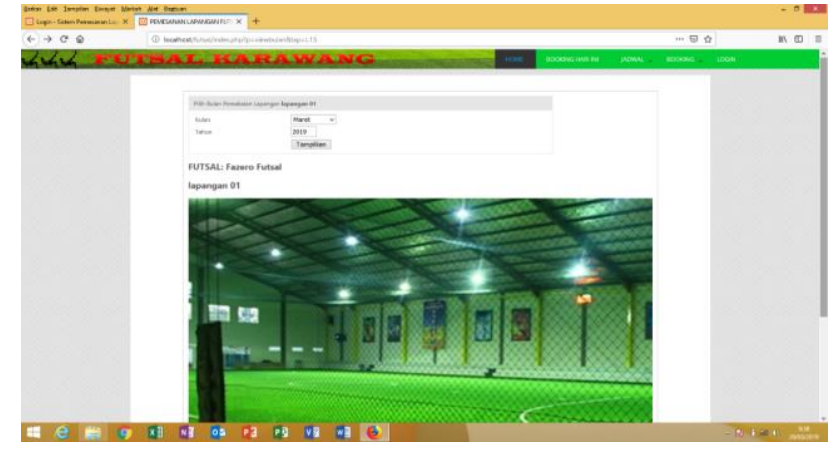

Fig. 7. Add booking page

E. Testing

Testing this Web-Based Futsal Field Ordering Information System software using the black box method. Black box testing focuses on the functional requirements of the admin login form and member login form software.

Table 1. Testing Web

\begin{tabular}{cccc}
\hline $\begin{array}{c}\text { GRADE } \\
\text { TEST }\end{array}$ & ITEM TEST & $\begin{array}{c}\text { TEST } \\
\text { LEVEL }\end{array}$ & TESTING TYPES \\
\hline LOGIN & Login & Integrasi & Black Box \\
& Admin & & \\
& Login User & Integrasi & Black Box \\
Testing & $\begin{array}{c}\text { Pengisian } \\
\text { Registrasi }\end{array}$ & Integrasi & Black Box \\
& User & & \\
Data & Pengisian & Integrasi & Black Box \\
Testing & Transaksi & & \\
\hline
\end{tabular}

\section{CONCLUSION}

From the results of field research and the website creation process, the authors conclude:

1. This photocell field ordering system can already be used. Implementing this web-based information system can make it easier for customers and managers of futsal fields to get information relating to the futsal venue, futsal field reservations.

2. In this futsal field booking website information systems can print proof of payment for futsal field bookings to reduce fraud in payments.unnumbered footnote on the first page.

\section{REFERENCES}

[1] Bayu Priyatna, "Penerapan Metode User Centered Design (Ucd) Pada Sistem Pemesanan Menu Kuliner Nusantara Berbasis Mobile Android," Account. Inf. Syst. PENERAPAN, Pp. 17-30, 2018.

[2] Black, M. J. \& Hawks, H. J., 2009.Medical surgical nursing: clinical management for continuity of care, 8th ed. Philadephia: W.B. Saunders Company

[3] Mulyanto Agus. 2009. Sistem Informasi Konsep dan Aplikasi. Pustaka Pelajar. Yogyakarta.

[4] Suryana, Taryana dan Koesheryatin. 2014. Aplikasi Internet Menggunakan HTML, CSS, \& JavaScript.Jakarta: PT Elex Media Komputindo.

[5] Wahyono, \& Teguh. 2004. Sistem Informasi Konsep Dasar, Analisis, Desain dan Implementasi. 
Graha Ilmu, Yogyakarta.

[6] Suryana, Taryana dan Koesheryatin. 2014. Aplikasi Internet Menggunakan HTML, CSS, \& JavaScript.Jakarta: PT Elex Media Komputindo. 